\title{
Climate Change and the Mediterranean Southern Coasts
}

\author{
G. Anfuso and D. Nachite
}

\section{Introduction}

Global climate change is a scientific hypothesis proposing that anthropogenic impacts on the environment, such as greenhouse gas emissions and land use, may be responsible for local and global climate changes at present and into the future. Furthermore, although anthropogenic emissions of greenhouse gases associated with the use of fossil fuels are mainly from the rich industrialized countries, the impacts of climate change will be more severe in poor developing countries. Any environmental impacts in the world's coastal zones may be significant because coastal development is continually expanding from current levels: projections are that approximately $75 \%$ of the global population of 7.1 billon in the year 2020 will live within $20 \mathrm{~km}$ of the coastline. Because of this, the effect of predicted global sea level rise (SLR) due to climate change has become one of the major concerns for coastal managers in recent years.

The local change in sea level at a particular coastal location and the interconnected coastal risks depends on the global mean SLR and regional deviation from this mean (Church and White, 2006). While the global SLR results from the expansion of the ocean due to the increase in ocean temperature and melting of ice caps, regional factors are caused by non-uniform patterns of temperature and salinity changes in the ocean. In detail, sea warming raises sea level whereas a salinity increase causes sea level to drop because of increased seawater density. Moreover, salinity contributions to SLR constitute at most $20 \%$ of the temperature contributions (Maes, 2000).

Locally, vertical land movements also occur due to various geological and human induced processes such as tectonics and isostatic adjustments, sediment loading, and underground water pumping and gas extraction.

In addition, commonly documented outcomes of climate change on coastal environments include changes on storm sequencing and storm arrival patterns, storm surge increase and tropical storm variability. However, a less documented 


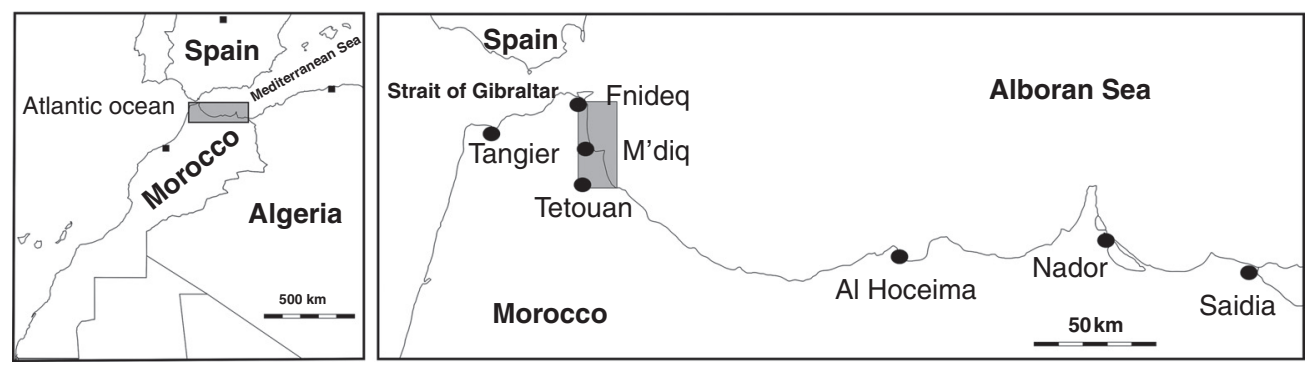

Fig. 8.1. Location map of the most important coastal cities along the Mediterranean littoral of Morocco.

aspect is greater wave climate variability, even if some studies have found that changes are already evident and many will continue into the future (Keim et al., 2004). In general, sea level variations are surveyed through high-precision satellite altimetry and tidal gauges; the latter are referenced by a point on land, thus including land movements that can significantly contaminate the sea level signal (Emery and Aubrey, 1991).

The present study deals with climate change effects in the Mediterranean littoral of Morocco, which is one of the most vulnerable countries within the Mediterranean region (GIEC, 2007), especially the low-lying areas located in the eastern, i.e. Nador and Saidia areas, and western parts, i.e. Tangier and Tetouan areas (Fig. 8.1).

According to the methodology proposed by GIEC (2001), the future scenario of climatic change in Morocco includes a clear increasing trend of the mean annual temperature, with values ranging from 0.6 to $1.1^{\circ} \mathrm{C}$ by 2020 ; a reduction in rainfall precipitation of $4 \%$ in 2020 , with respect to the figures for 2000 ; an increase of the frequency and intensity of dry periods in the southern and eastern parts of the country; changes in the rainfall precipitation with winter rainfall concentrated in a short period and a reduction in the duration of snowing period and in the extension of ice cover.

The aforementioned changes will greatly impact most vulnerable activities, i.e. tourism and agricultural activities, which are especially developed in coastal areas. Different aspects of climatic change characteristics and impacts will be analysed in following sections.

\section{Sea Level Rise Trend in the Mediterranean Littoral of Morocco}

Tsimplis and Baker (2000) used tide gauges to study SLR for the coastal Mediterranean Sea. A negative trend, because of an increase in average atmospheric pressure, was observed during the 1960-1990 period while an average increase of $1.1-1.3 \mathrm{~mm} /$ year was recorded for the 20th century. Cazenave et al. (2001) investigated sea level changes in the Mediterranean Sea in the 1993-1999 period through data obtained by the Topex/Poseidon space mission, which 
provided absolute measurements of sea level variations. Authors observed that the Mediterranean sea level has been rising almost everywhere since early 1993. In detail, according to Cazenave et al. (2001), within the western Mediterranean, sea level is increasing $5-10 \mathrm{~mm} /$ year in the Alboran Sea, i.e. south-east Spain and north-east Morocco Mediterranean littoral areas, which was confirmed by tidal gauge data at Malaga and Alicante.

There are several possible causes for the recent sea level trend observed in the Mediterranean Sea. In detail, the observed trend essentially depends on seawater volume change due to density changes in response to temperature and salinity variations, and mass change due to water exchange with the atmosphere and land through precipitation, evaporation and river runoff, and exchange of water through the Gibraltar Strait (Ross et al., 2000). Quantitative estimations of each contribution for the 1993-1999 period were not feasible due to the lack of suitable observations. Cazenave et al. (2001) were able to correlate sea surface temperature trend with observed SLR, obtaining a correlation coefficient of 0.72 for the whole Mediterranean Sea, the detailed spatial pattern showing that surface warming has been about twice as large in the eastern than in the western basin. Cyclic variations are superimposed on the trend, with periods around 2-3 and 4-5 years.

Noticeable increase of the temperature and salinity of deep waters of the western Mediterranean Sea has been observed by several hydrographical studies conducted since the 1960s (Bethoux et al., 1990, 1998). Salinity increase has been attributed to freshwater deficit due to reduced rainfall in the 1990s and damming of major rivers for agricultural purposes (Bethoux et al., 1998; Bethoux and Gentili, 1999). Overall, for the western Mediterranean Sea, Ross et al. (2000) affirmed that hydraulic changes of surface and deep water flow through the Strait of Gibraltar may participate in raising sea level. Fenoglio-Marc et al. (2004) used differences in sea surface heights measured by tide gauges and Topex/ Poseidon altimeter to estimate vertical land movement in the Mediterranean region, obtaining smaller rates in the north-western area.

More recent studies, i.e. Marcos and Tsimplis (2008), used available tide gauge records for the period 1960-1990 to investigate sea level trends in the Mediterranean Sea and Atlantic Iberian coasts. They separated the direct atmospheric forcing and steric contributions from the other forcing factors and presented the residual trends. By this means, Marcos and Tsimplis used the HIPOCAS (Hindcast of Dynamic Processes of the Ocean and Coastal Areas of Europe) data to correct atmospheric pressure and wind-induced sea level variations and MEDAR database for the Mediterranean Sea to correct temperature and salinity related sea level variations. The postglacial rebound was considered for the Mediterranean in the order of $\pm 0.3 \mathrm{~mm} /$ year. The authors utilized Cádiz, Tarifa, Málaga and Ceuta tide gauge records, with data spanning from 40 to 60 years, to try to reconstruct sea level trend in the Gibraltar Strait area. They observed important variations between the tide gauge records, which prevented a common value being calculated for the area. In detail, tide gauges recorded sea level rise at Málaga ( $2.4 \pm 0.4 \mathrm{~mm} /$ year) and Ceuta $(0.6 \pm 0.1 \mathrm{~mm} /$ year $)$ and steric contributions in Ceuta were evaluated as $-2.1 \pm 0.6 \mathrm{~mm} /$ year.

Naizi (2007) affirmed that no data are available on land movement and local SLR causes in the Tetouan region, and proposed a SLR value of 
$2.5 \mathrm{~mm} /$ year, which is the value obtained for the western Mediterranean Sea by the Topex/Poseidon and Jason-1 satellite mission during the 1993-2006 period. The author, in order to estimate maximum and minimum hypothetical storm surge elevations for the western Mediterranean littoral of Morocco, took into account two hypotheses: (i) no increase of present SLR trend, i.e. sea level would record an increase of 15 and $27.5 \mathrm{~cm}$ by 2050 and 2100, respectively; and (ii) rapid increase of SLR trend, with different scenarios and associated SLR values ranging between 21 and $47 \mathrm{~cm}$ by 2050 and between 36.5 and $115.5 \mathrm{~cm}$ by 2100 .

Lastly, for both the eastern and western Mediterranean areas (Fig. 8.1), Warrick et al. (1996) proposed SLR values ranging from 20 to $86 \mathrm{~cm}$ for 2100 , with a best estimate value of $49 \mathrm{~cm}$.

\section{Coastal Erosion and Flooding Hazards}

The impact of climate change will acquire a great importance on littoral areas because of coastal erosion and flooding processes, which will be emphasized by SLR, especially considering that almost all the Morocco Mediterranean beaches are recording important erosion processes (Nachite, 2009) and are heavily urbanized (Fig. 8.2). In the 1958-2003 period, the littoral of Tetouan recorded coastal retreat rates of $2 \mathrm{~m} /$ year (Anfuso et al., 2007; Nachite, 2007), and lost about $3,900,000 \mathrm{~m}^{2}$ of beach surface (Niazi, 2007); it presents a great vulnerability to coastal flooding (Benavente et al., 2007).
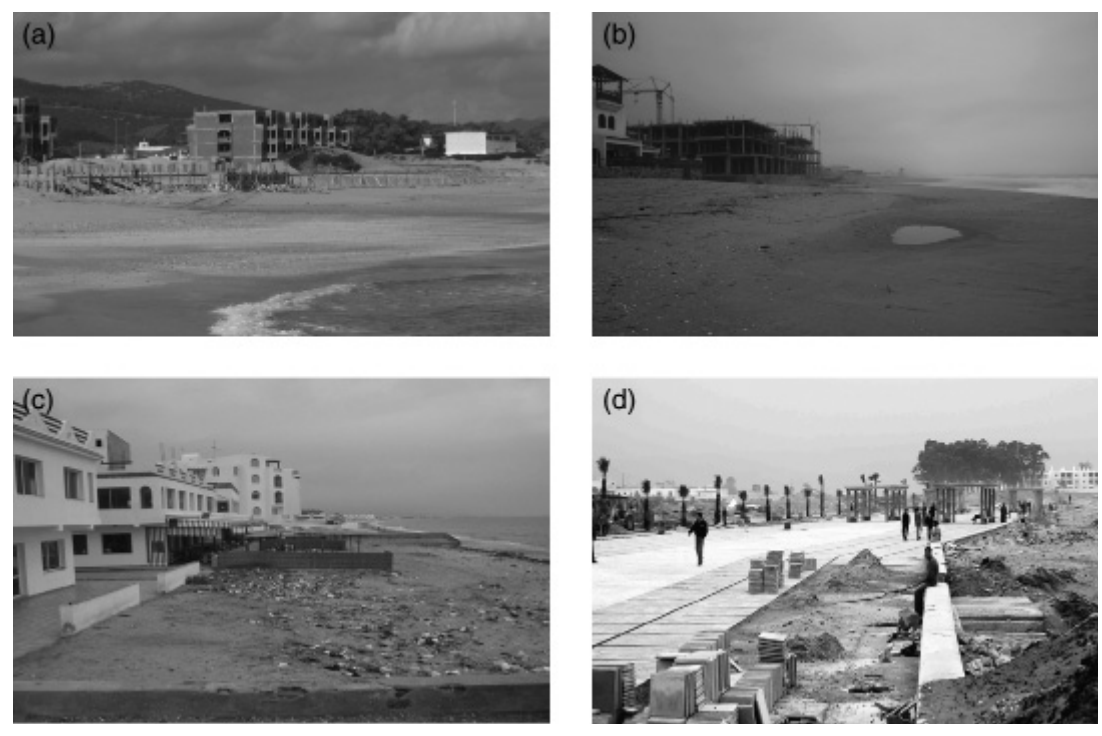

Fig. 8.2. Human structures on the backshore and dune ridges. Buildings under construction south of Marina Smir (a and b, photo May 2006), summer houses (c, photo October 2003) and a promenade (d, photo May 2006) at M'diq. 
According to the previous observations, erosion and flooding processes will affect economic activities and human settlements in different areas, generating a great impact on tourist activities, which represent the most important income for the country. The effects of erosion and flooding processes on different sectors, i.e. Tangier and Tetouan, in the western littoral, and Saidia-Ras $\mathrm{El} \mathrm{Ma-Al} \mathrm{Hoceiema} \mathrm{in} \mathrm{the} \mathrm{eastern} \mathrm{Mediterranean} \mathrm{littoral} \mathrm{(Fig.} \mathrm{8.1)} \mathrm{will} \mathrm{be}$ described here. The littoral between the last two areas is essentially composed by cliffed sectors that do not record erosion or flooding processes and have very limited tourist and economic activities.

Snoussi et al. (2009), following SLR values proposed by Warrick et al. (1996), estimated that $10 \%$ and $24 \%$ of the area of Tangier will be at risk of flooding for minimum and maximum hypothetical storm surge elevations of 4 and $11 \mathrm{~m}$, respectively. Beaches $(97 \%$ and $99.9 \%$, respectively, for the minimum and maximum storm surge elevations), tourist $(69.1 \%$ and $84.5 \%)$ and harbour $(97.5 \%$ and $99.9 \%$ ) infrastructures will be heavily impacted and shoreline erosion would affect nearly $20 \%$ and $45 \%$ of the total beaches, in 2050 and 2100 , respectively.

For the Tetouan area, Niazi (2007) forecasted the flooding of $20 \%$ and $27 \%$ of the coastal area and important damage for $57 \%$ and $63 \%$ of urbanized areas of Fnideq, M'diq, Cabo Negro, Martil and Tetouan because of hypothetical storm surge elevations of 5 and $10 \mathrm{~m}$, respectively. The littoral between Cabo Negro and Martil essentially comprises a low lying coastal plain that is very exposed to flooding processes (Fig. 8.3), which would produce the loss of about $25 \%$ of its original extension.

According to Snoussi et al. (2008), in the eastern Mediterranean littoral, $24 \%$ and $59 \%$ of the littoral located between Cape Ras El Ma and Saidia village will be flooded for minimum and maximum hypothetical storm surge elevations of 2 and $7 \mathrm{~m}$, respectively. The most severely impacted sectors are expected to be the residential, recreational and agricultural areas, and natural areas with their important ecosystems. Shoreline erosion will affect $50 \%$ and $70 \%$ of area in 2050 and 2100 , respectively.

Lastly, river-flooding processes will affect economic activities and human settlements in low lying areas close to rivers, especially because of the inappropriate and heavy (94\%) urbanization of these areas. In the Mediterranean region, river-flooding processes acquire a great importance because of the characteristics of river basins (high slopes, low vegetal cover, high rates of soil erosion: 3000 $\mathrm{t} / \mathrm{km}^{2} /$ year as observed by Oubalkace (2007) along most of the Mediterranean river basins) and location of human settlements (more than 80 villages present a great risk of inundation). Examples of this during last decades have been the flooding in the Tetouan-Martil (1996, 1998, 2000) and Al Hoceima (2003, 2004, 2008) areas, which produced huge damage and loss of human lives (Fig. 8.4).

\section{Water Management Problems}

The regional increase of temperatures and lower levels of precipitation over the last decades, and the inter-annual seasonal variability and changes in precipitation 


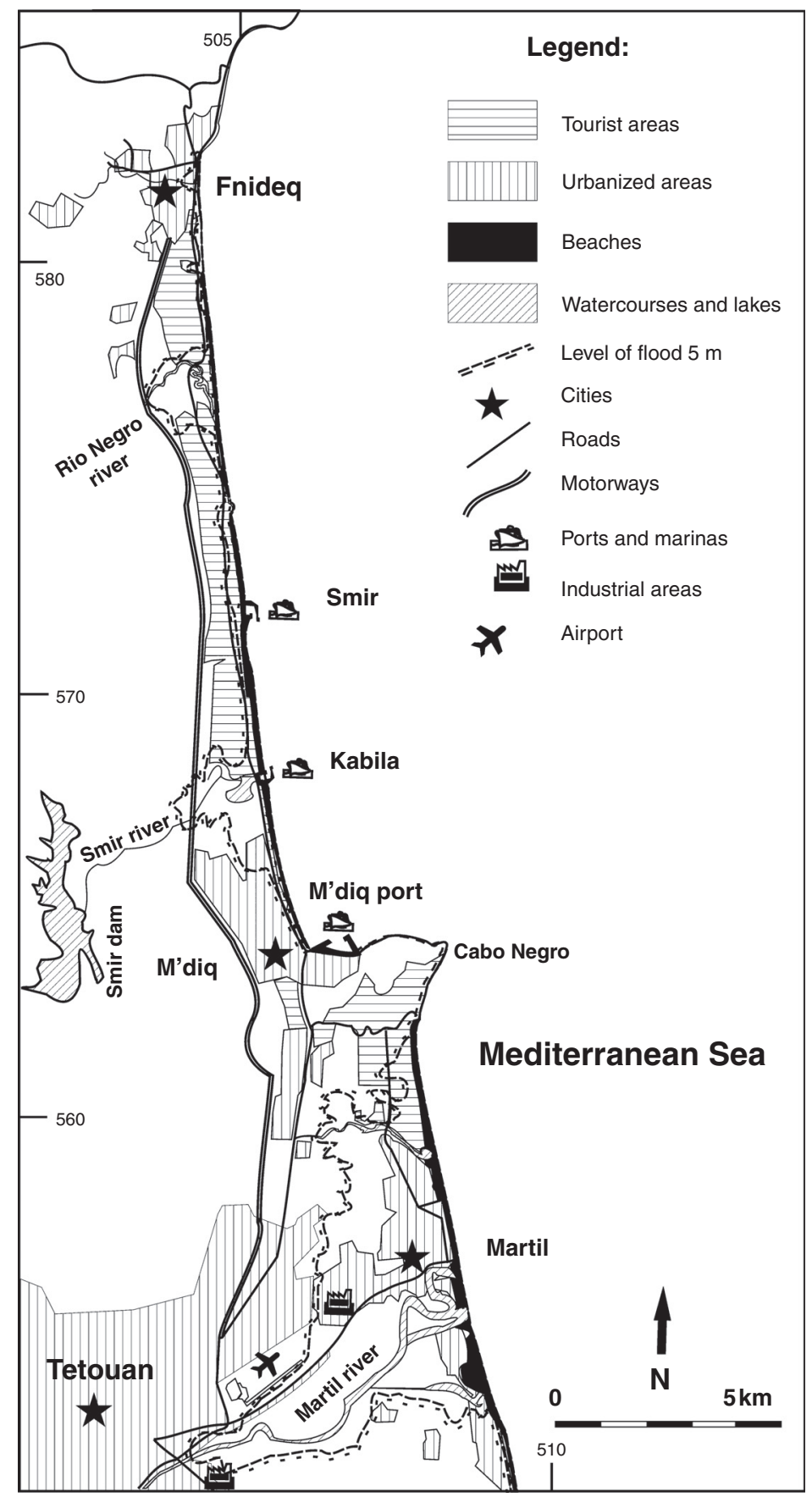

Fig. 8.3. Land uses and vulnerability to flooding, for the $5 \mathrm{~m}$ maximum storm surge case, for the area between Fnideq and M'diq. Modified from Nachite $(2007,2008)$ and Niazi (2007). 


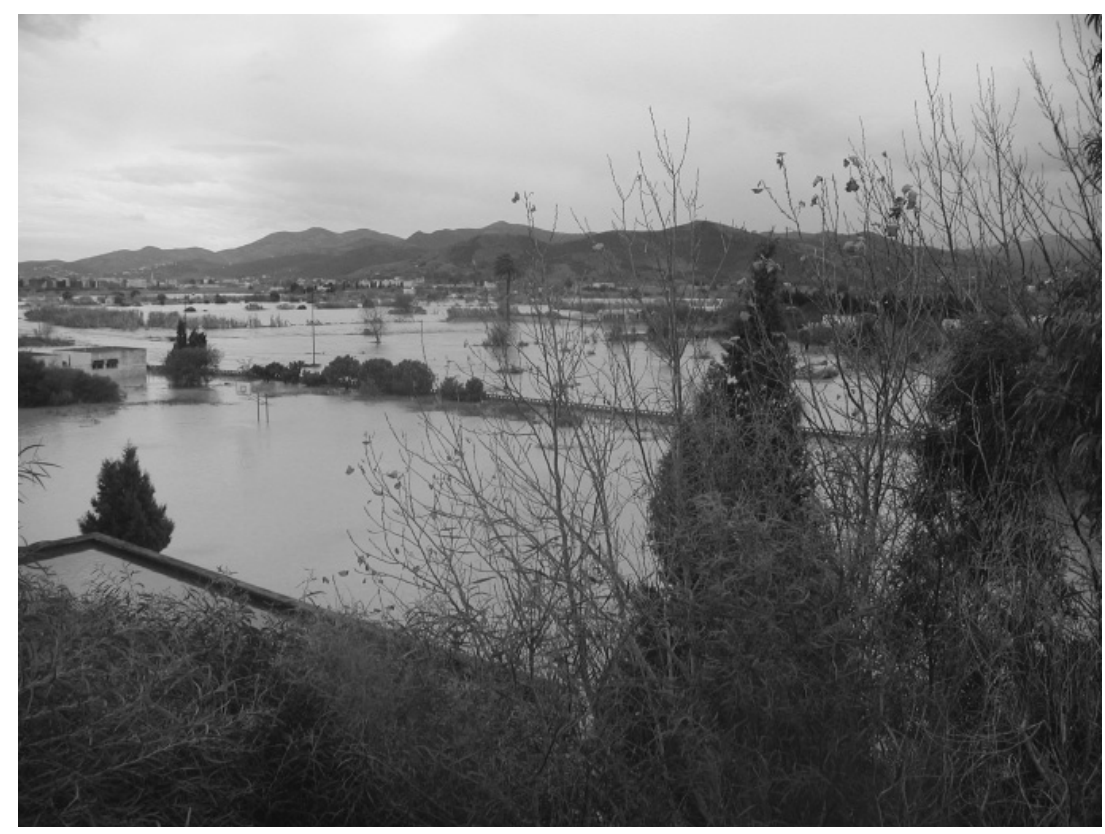

Fig. 8.4. Flooding at Tetouan on 27 December 2000.

distribution, make water resource management an important and imperative issue in Morocco, especially in the Mediterranean littoral, which is a semi-arid region (Tekken et al., 2009). It must also be taken in mind that agricultural and tourism-related activities, which are well developed in the Mediterranean littoral, are highly water consuming.

Today, water resource difficulties cover the basic human necessities, water availability ranging from 180 to $1850 \mathrm{~m}^{3} /$ person/year for the southern and northern parts of Morocco, respectively. MATEE (2001) predicted a scenario by the year 2020 of a decrease for water resources of $10-15 \%$, with an average national value of $720 \mathrm{~m}^{3} /$ person/year. By the 2020 scenario, according to the previous predictions, about 14 millions inhabitants (i.e. $35 \%$ of the total population) will have less than $500 \mathrm{~m}^{3} /$ person/year (Oubalkace, 2007).

Alibou (2002) predicted, by 2020 , a decrease of $3.3 \%$ and $2.3 \%$ of rainfall, respectively, for the north-western and eastern sectors of the Mediterranean littoral of Morocco. It is estimated that this situation will produce a deficit of 109 million $\mathrm{m}^{3} /$ year in the Tangier, Loukkos and other Mediterranean coastal basins, and of 60 million $\mathrm{m}^{3} /$ year in the Mouloya basin (Oubalkace, 2007). For the latter area (i.e. Moulouya basin), Tekken et al. (2009) observed that average annual precipitation dropped about $10 \%$ in the last century, with most important decreases recorded in spring, winter and autumn and small increases in summer, the latter being too marginal to contribute to the regional water balance because of high summer evapotranspiration values. 
Groundwater resources are threatened by changing temperature and precipitation and damming, intensive withdrawal of water and SLR. As a result, coastal aquifers along the Mediterranean littoral are presently experiencing sea water intrusion especially in the lower coastal plains. Example of this are observed at Smir, Martil-Alila, Oued Laou, Ghis-Nekor, Bouareg and at the coastal plain of Saidia (ABHL, 2006; Meneoui, 2008; Nachite 2009). Niazi (2007) predicted vulnerability to sea water intrusion for $45 \%$ and $52 \%$ of Smir and $30 \%$ and $46 \%$ of Martil-Alila aquifers, by the 2050 and 2100 scenarios, respectively.

All these previous problems will be greatly emphasized by temperature increase, which will produce a migration of vegetation and a consequent expansion of arid zones towards the north, i.e. an increase of desertification processes. Not only human activities are threatened by temperature and precipitation changes but also several coastal lagoons of great ecological interest, i.e. Kabila, Smir and Nador (Castro et al., 2006).

\section{Agricultural and Tourist activities}

In Morocco, agriculture and farming are basic activities of the local economy that contribute to smallholder subsistence. Agriculture employs approximately $60 \%$ of the working population and utilizes more than the $80 \%$ of the total amount of water resources; as a result, it will be greatly affected by the reduction of water availability. From present predictions to a 2020 scenario, the Cropwat Model (FAO, 2001) predicted a decrease in the winter cultivation of cereals by $10 \%$ and $50 \%$ in normal and dry years, respectively, with a reduction at national level of about $30 \%$. Thibault (2008) predicted an increase in the necessity of water for irrigation purposes, a reduction in the duration of the vegetative cycles of cultures, an increase of soil erosion, and a reduction of agricultural activities in littoral areas because of sea water intrusion in soils and aquifers, especially in the Mediterranean region, where most of the agricultural lands are located on the coastal plain.

Human occupation of littoral areas has also been growing during the last decade, with 2,532,714 inhabitants, $8 \%$ of the total population of Morocco, living in the Mediterranean littoral. Most of the cities of the northern area of Morocco are coastal cities (15 out of 20). The seasonal character of tourism in the area produces a doubling of the population during summer (July and August), which is essentially constituted by national tourists. Most important tourist beaches are Saidia, Nador, Al Hoceima and littoral areas of Tangier and Tetouan (Fig. 8.1).

At Saidia, the growth in coastal area occupation was about $9 \%$ per annum for the period 2004-2010 (taking into account constructed and projected buildings) and urbanized areas are projected to be about $75 \%$ of the whole coastal area by 2010. The same processes achieve critical dimensions in the western part of the littoral; in fact in the Tetouan littoral area, about $40 \mathrm{~km}$ long, coastal occupation was about $95 \%$ in 2007, with an average growth of occupation for the 1969-2007 period of $2 \%$ per annum, with maximum values of $5 \%$ per annum for the 2004-2007 period (Nachite, 2008). 
Dealing with such tourist activities, the conference on tourism held in Marrakech in 2001 marked a turning point in the tourism policy of Morocco, which opted for the promotion of the tourist sector, putting in place an ambitious strategy named 'Vision 2010': as such, tourism is supposed to play a principal role in socio-economic development of the country.

The 'Vision 2010' objectives are very ambitious (both in terms of quantity and quality): (i) the arrival of 10 million tourists by 2010; (ii) the increase of hotel capacity of 160,000 beds $(130,000$ in coastal tourist resorts and 30,000 in cultural destinations of the country), putting the national capacity up to 230,000 beds; (iii) the increase of investments, the volume being expected to reach 8 to 9 billion Euros, because of the planning of new sea tourist resorts, infrastructure, hotels, leisure and entertainment; (iv) revenues expansion expected to reach 48 billion Euros; (v) the creation of 600,000 new jobs; and (vi) the increase of tourism contribution to the GDP, which is forecast to rise annually from today's $8.5 \%$ average, to be about $20 \%$ by 2010 .

The plan is essentially based on the increase of coastal and beach-related tourism through the 'Plan Azure' and 'Azure extension' focused on littoral tourism. The main aim is to increase, by 2015 , beach tourism to $70 \%$ of the total offer at national scale and to $90 \%$ at the Mediterranean littoral.

Several problems potentially arise from the present tourist development trends and the 'Vision 2010' plan, i.e. a chronic deficit of water resources and a large increase in the population living on the littoral. Substantial increases in water demand are also linked to the 3 million tourists that visit Morocco each year and which require $30 \%$ more water than a local person. Furthermore, they produce about 1801 of waste water per person (EEA, 2000). In addition, Morocco is going to receive about 172,000 tourists for playing golf (ONMT, 2006) by 2010, and the Mediterranean littoral especially will record a great increase in the construction of golf camps, this way highlighting the necessity of new, important water resources.

\section{Conclusions}

Although many European countries have qualitative data on SLR and climatic change processes and related effects and impacts, further studies must be carried out in Morocco to properly understand the potential physical and social consequences of such processes. In particular, the following areas will require special attention.

- Coastal erosion and flooding processes will generate, in the near future, important losses of beach and coastal area surfaces, this way producing severe economic damage to coastal tourism, the main economic activity for the Mediterranean littoral of Morocco.

- Rainfall diminution, sea water intrusion and excessive groundwater exploitation are generating an increase in the water demand-supply gap. This issue will seriously penalize both tourism developments and agricultural activities, the latter representing the unique income for a large part of the rural population of Morocco. 
Lastly, in Morocco, appropriate vulnerability assessment and adaptation strategies to SLR and climate change are required at regional and national scale to improve the tools for correct coastal zone management. During recent decades, these have been greatly neglected because of more urgent requirements and problems or essentially the wish to create rapid economic growth linked to coastal urbanization and tourism.

\section{References}

ABHL - Agence du Bassin Hydraulique du Loukkos (2006) Les ressources en eau au niveau de la zone d'action de l'Agence du Bassin Hydraulique du Loukkos: Etat des lieux et perspectives de leur développement et leur sauvegarde. Débat national sur l'eau, November 2006, 29pp.

Alibou, J. (2002) Impact des changements climatiques sur les ressources en eau et les zones humides du Maroc. Table Ronde Régionale en Méditerranée Athènes, Grèce, 10-11 December 2002, 41pp.

Anfuso, A., Martinez del Pozo, J.A., Nachite, D., Benavente, J. and Macias, A. (2007) Morphological characteristics and medium-term evolution of the beaches between Ceuta and Cabo Negro (Morocco). Environmental Geology 52, 933-946.

Benavente, J., Bello, E., Anfuso, G., Nachite, D. and Macias, A. (2007) Sobreelevación debida a temporales y cambios producidos en las playas del litoral NE marroquí. Cuaternario \& Geomorfología 21(1), 13-15.

Bethoux, J.P. and Gentili, B. (1999) Functioning of the Mediterranean Sea: past and present changes related to freshwater input and climate changes. Journal Marine Systems 20, 33-47.

Bethoux, J.P., Gentili, B., Raunet, J. and Tailliez, D. (1990) Warming trend in the western Mediterranean deep water. Nature 347, 660-662.

Bethoux, J.P., Gentili, B. and Tailliez, D. (1998) Warming and freshwater budget change in the Mediterranean since the 1940s, their possible relation to the greenhouse effect. Geophysical Research Letters 25, 1023-1026.

Castro, M., Arroyo, G., Bekkali, R., Nachite, D. and Anfuso, G. (2006) Características ambientales del entorno de la laguna de Smir. In: Anfuso, G. and Nachite, D. (Coords). Dep. Legal: CA/206/06. 40pp.

Cazenave, A., Cabanes, C., Dominh, K. and Mangiarotti, S. (2001) Recent sea level change in the Mediterranean Sea revealed by Topex/Poseidon satellite altimetry. Geophysical Research Letters 28(8), 1607-1610.

Church, J.A. and White, N.J. (2006) A 20th century acceleration in global sea level rise. Geophysical Research Letters 33(1), L01602, doi: 10.1029/2005GL024826.

EEA (2000) State and Pressure of the Marine and Coastal Mediterranean Environment. Office for Official Publications of the European Communities (Environmental assessment report, no 5), Luxembourg.

Emery, K.O. and Aubrey, D.G. (1991) Sea Levels, Land Levels and Tide Gauges. Springer, Berlin, 237pp.

FAO (2001) CropWat Model, version 7.0. www.fao.org/ag/AGL/aglw/cropwat.stm (Accessed: 10 January 2009).

Fenoglio-Marc, L., Dietz, C. and Groten, E. (2004) Vertical land motion in the Mediterranean Sea from altimetry and tide gauge stations. Marine Geodynamics 27(3), 683-701. 
GIEC (2001) Climate Change 2001: The scientific Basis. Contribution of Working Group I to the Third Assessment Report of the Intergovernmental Panel on Climate Change, Cambridge. Cambridge University Press.

GIEC (2007) Groupe de travail I du GIEC. Quatrième Rapport d'évaluation, Bilan 2007 des changements climatiques les bases scientifiques physiques, Résumé à l'intention des décideurs, 25pp.

Keim, B., Muller, R. and Stone, G. (2004) Spatial and temporal variability of coastal storms in the North Atlantic Basin. Marine Geology 210, 7-15.

Maes, C. (2000) Salinity variability in the equatorial Pacific ocean during the 1993-1998 period. Geophysical Research Letters 27, 1659-1662.

Marcos, M. and Tsimplis, M. (2008) Coastal sea level trends in Southern Europe. Geophysical Journal International 175, 70-82.

MATEE (2001) Communication Nationale Initiale à la Convention Cadre des Nations Unies sur les changements climatiques, October 2001, 101pp.

Meneoui, M. (2008) Vulnérabilité des écosystèmes du Littoral Méditerranéen Oriental à l'élévation du niveau de la mer. Projet ACCMA, 44pp.

Nachite, D. (2007) Le développement touristique du littoral de la région TangerTétouan: une évolution vers des scénarios non désirables? In: Géologie et géotourisme dans la rive sud du détroit de Gibraltar. Aula universitaria del Estrecho, pp. 53-72.

Nachite, D. (2008) L'aménagement touristique de la côte méditerranéenne du Maroc et ses impacts environnementaux. Journées internationales de sensibilisation aux enjeux de la Gestion Intégrée des Zones côtières (GIZC) dans le bassin méditerranéen et en Amérique latine ». 9-11 January 2008 (Projet LITMED 21), Université de Nice Sophia-Antipolis - France. http://podcast.unice.fr/groups/conferences/weblog/68c1d/ (Accessed: 10 January 2009).

Nachite, D. (2009) Diagnostic environnemental - PAC Rif central du Maroc, activité GIZC, PAP/CAR, January 2009, 74pp.

Niazi, S. (2007) Evaluation des impacts des changements climatiques et de l'élévation du niveau de la mer sur le littoral de Tétouan (Méditerranée occidentale du Maroc): Vulnérabilité et Adaptation. Doctorat es-sciences Univ. Mohammed V - Agdal (Maroc), 296pp.

ONMT (2006) Le Maroc se fixe pour objectif d'accueillir plus de 172.000 touristes golfeurs en 2010. Office National Marocain du Tourisme. MAP, 30 June 2006. www.fmdt.ma/details.php?id=2757 (Accessed: 10 January 2009).

Oubalkace, M. (2007) Suivi des progrès et promotion de politiques de gestion de la demande en eau: Rapport national du Maroc. Gestion de la demande en eau en Méditerranée, progrès et politiques. ZARAGOZA, 19-21 March 2007, 121pp.

Ross, T., Garett, C. and Le Traon, P.Y. (2000) Western Mediterranean sea level rise: changing exchange flow through the Strait of Gibraltar. Geophysical Research Letters 27(18), 2949-2952.

Snoussi, M., Ouchani, T. and Niang-Diop, I. (2009) Impacts of sea-level rise on the Moroccan coastal zone: quantifying coastal erosion and flooding in the Tangier Bay. Geomorphology 107(1-2), 32-40.

Snoussi, M., Ouchani, T. and Niazi, S. (2008) Vulnerability assessment of the impact of sea-level rise and flooding on the Moroccan coast: The case of the Mediterranean eastern zone. Estuarine, Coastal and Shelf Science 77, 206-213.

Tekken, V., Costa, L. and Kropp, J.P. (2009) Assessing the regional impacts of climate change on economic sectors in the low-lying coastal zone of Mediterranean east Morocco. Journal of Coastal Research (Special Issue) 56, 272-276. 
Thibault, H.L. (2008) Changement climatique et energie en mediterranee. Plan Bleu, Centre d'Activités Régionales, Sophia Antipolis, July 2008, 49pp.

Tsimplis, M.N. and Baker, T.F. (2000) Sea level drop in the Mediterranean Sea: an indicator of deep water salinity and temperature changes? Geophysical Research Letters 27(12), 1731-1734.

Warrick, R.A., Le Provost, C., Meier, M.F., Oerlemans, J. and Woodworth, P.L. (1996) Changes in sea level. In: Houghton, J.T., Meira Filho, L.G., Callander, B.A., Harris, N., Kattenberg, A. and Maskell, K. (eds) Climate Change 1995. The Science of Climate Change. Cambridge University Press, Cambridge, UK, 365-405. 